DOI: https://doi.org/10.24127/ajpm.v10i3.3533

\title{
PEMBELAJARAN MATEMATIKA SECARA DARING MEMBOSANKAN BAGI SISWA SEKOLAH DASAR: STUDI SELF-REPORT SISWA
}

\section{Yoppy Wahyu Purnomo ${ }^{1 *}$, Jihan Luthfi Salsabila ${ }^{2}$, Ainun Nafisah ${ }^{3}$, Rizki Dwi Rahmawati $^{4}$, Fidariya Mawaddah ${ }^{5}$}

\author{
$1^{*}, 2,4,5$ Universitas Negeri Yogyakarta, Yogyakarta, Indonesia \\ ${ }^{3}$ Universitas Sebelas Maret, Surakarta, Indonesia \\ *Corresponding author. Universitas Negeri Yogyakarta, Yogyakarta, Indonesia. \\ E-mail: $\quad$ yoppy.wahyu@uny.ac.id ${ }^{1)^{*}}$ \\ jihanluthfi.2018@student.uny.ac.id ${ }^{2)}$ \\ ainunnafisah814@student.uns.ac.id ${ }^{3)}$ \\ rizki124.2018@student.uny.ac.id ${ }^{4)}$ \\ fidariyamawaddah.2018@student.uny.ac.id ${ }^{5)}$
}

Received 05 February 2021; Received in revised form 21 June 2021; Accepted 05 September 2021

\begin{abstract}
Abstrak
Penelitian ini bertujuan untuk mengetahui persepsi siswa sekolah dasar dalam pembelajaran matematika secara daring sehingga dapat ditentukan langkah lebih lanjut untuk memperbaiki sistem pembelajaran matematika daring jika terdapat kekurangan atau kelemahan dalam proses pembelajarannya. Metode survei dan studi kasus digunakan untuk menggapai tujuan. Partisipan dalam penelitian ini adalah 79 siswa kelas empat di salah satu sekolah dasar yang ada di Bantul. Data diambil menggunakan kuesioner persepsi dan dieksplorasi lebih lanjut melalui wawancara kepada 6 siswa berdasarkan level kognisinya. Analisis deskriptif digunakan untuk menggambarkan kecenderungan data. Di samping itu, transkrip rekaman wawancara dikodekan masing-masing peneliti berdasarkan pola menarik dan kemudian didiskusikan. Triangulasi sumber digunakan untuk menjamin keakuratan hasil. Hasil penelitian menunjukkan bahwa persepsi siswa terhadap pembelajaran matematika secara daring cenderung mengarah pada persepsi negatif. Tidak menarik, membosan, tidak efektif mungkin adalah kata-kata yang tepat menggambarkan sikap mereka. Selain itu, ditemukan bahwa level kognisi tidak mesti sejalan dengan minat dan motivasi siswa. Literasi teknologi dan inovasi pembelajaran yang sesuai dengan zamannya menjadi penting untuk diperhatikan sebagai upaya memfasilitasi guru dan siswa dalam pembelajaran matematika secara daring.
\end{abstract}

Kata kunci: Matematika; pembelajaran daring; persepsi; sekolah dasar.

\begin{abstract}
This study aims to determine the perception of elementary school students in online mathematics learning so that further steps can be determined to improve the online learning system in mathematics subjects if there are deficiencies or errors in the learning process. Survey methods and case studies are used to achieve the objectives. The participants in this study were 79 fourth-grade students in an elementary school in Bantul. The data was taken using a perception questionnaire and further explored through interviews with six students based on their level of cognition. Descriptive analysis is used to describe the trend of the data. In addition, transcripts of recorded interviews were coded according to interesting patterns among researchers and then discussed. Source triangulation is used to ensure the accuracy of the results. The results showed that students' perceptions of learning mathematics online tend to lead to negative perceptions. Unattractive, boring, ineffective are probably the right words to describe their attitude. In addition, it founded that the level of cognition is not necessarily in line with students' interests and motivations. Technological literacy and learning innovations that are in accordance with the times are important to pay attention to facilitate teachers and students in online learning.
\end{abstract}

Keywords: Mathematics; online learning; perception; elementary school.

This is an open access article under the Creative Commons Attribution 4.0 International License 
DOI: https://doi.org/10.24127/ajpm.v10i3.3533

\section{PENDAHULUAN}

Pembelajaran daring merupakan pembelajaran yang dilaksanakan tanpa tatap muka langsung dengan berbantuan fasilitas internet (Moore et al., 2011). Pembelajaran ini "terpaksa" dilaksanakan di masa pandemi Covid19 dan menjadi sebuah tantangan ketika materi yang disampaikan berkaitan dengan konsep-konsep terstruktur dan saling terkait, seperti matematika. Peralihan sistem pembelajaran dari luring menuju daring yang sangat cepat ini menyebabkan "kekagetan" akademik baik dari sisi persiapan guru, murid, orang tua, hingga sarana dan prasarananya. Oleh karena itu penting mengkaji persepsi mereka tentang bagaimana pembelajaran daring tersebut, khususnya untuk pembelajaran matematika.

Matematika menjadi salah satu mata pelajaran yang berorientasi pada kemampuan pemecahan masalah, berpikir tingkat tinggi, dan juga kreativitas. Dengan demikian, metode penyampaiannya kepada siswa harus berorientasi pada proses. Hal ini menjadi tantangan tersendiri dalam mendesain pembelajaran matematika secara daring.

Anak, termasuk dalam kontek ini adalah siswa sekolah dasar, cenderung mempersepsikan matematika sebagai kumpulan angka yang meliputi kegiatan berhitung dan bernyanyi (c.f., Metzger et al., 2019; Wernet \& NurnbergerHaag, 2015), meskipun persepsi tersebut tidak sepenuhnya benar, namun mereka lebih cenderung senang melibatkan diri mereka dalam belajar dengan alasan tersebut.

Di dalam batang tubuh penelitian pendidikan matematika, persepsi menjadi sebuah variabel kunci dalam perkembangan dan perbaikan pembelajaran matematika karena berkaitan dengan sikap proposisional, disposisi dan keterampilan awal matematika serta mempengaruhi praktik yang dipilih dalam belajar (Metzger et al., 2019; Purnomo et al., 2016). Dengan demikian, persepsi siswa tentang matematika dapat memengaruhi cara mereka memandang matematika dan cara mempelajari materi matematika (Markovits \& Forgasz, 2017).

Persepsi adalah pengetahuan subjektif yang dapat diidentifikasi melalui sikap proposisional (Purnomo, 2017a, 2017b; Purnomo et al., 2016). Persepsi seseorang berkaitan dengan proses memperoleh pengetahuan mengenai objek sesuatu pada saat tertentu. Dengan demikian, persepsi antara orang satu dengan yang lain sangat dimungkinkan berbeda.

Dalam konteks penelitian di Indonesia, beberapa penelitian yang berkaitan dengan persepsi siswa terhadap pembelajaran secara daring menunjukkan persepsi kurang baik (Ningsih, 2020; Rasmitadila et al., 2020; Zamista et al., 2020). Namun demikian, penelitian tersebut dan yang terdapat dalam literatur belum banyak memfokuskan pada konteks siswa sekolah dasar dan matematika. Oleh karena itu, tujuan penelitian ini difokuskan untuk mengetahui persepsi siswa sekolah dasar terhadap pembelajaran matematika secara daring.

\section{METODE PENELITIAN}

Metode yang digunakan dalam penelitian ini adalah metode survei cross-sectional dan dilanjutkan dengan studi kasus. Subjek penelitian ini adalah 79 siswa kelas empat pada salah satu Sekolah Dasar di Kabupaten Bantul. Partisipan dipilih dengan teknik purposive sampling dengan menentukan secara langsung subjek penelitian. Total keseluruhan populasi adalah 81 siswa. 
DOI: https://doi.org/10.24127/ajpm.v10i3.3533

Mereka berada pada rentang usia 9 dan 11 tahun. Detail partisipan dapat dilihat pada Tabel 1.

Tabel 1. Profil partisipan survei

\begin{tabular}{llcc}
\hline \multicolumn{1}{c}{ Berdasarkan } & Jumlah & $\%$ \\
\hline Kelas & 4A & 26 & 32,9 \\
& 4B & 26 & 32,9 \\
Jenis & 4C & 27 & 34,2 \\
Kelamin & Laki-laki & 33 & 41,8 \\
Umur & Perempuan & 46 & 58,2 \\
& 9 tahun & 26 & 32,9 \\
& 10 tahun & 52 & 65,8 \\
Pendidikan & SD tahun & 1 & 1,3 \\
terakhir & SMP & 19 & 12 \\
orang tua & SMA/SMK & 36 & 22,8 \\
& D-1/D-2/D-3 & 67,6 \\
& D-4 / S-1 & 4 & 3,8 \\
& S-2 & 2 & 1,3 \\
Pekerjaan & Buruh & 74 & 46,8 \\
orang tua & Karyawan & 17 & 10,8 \\
& PNS & 5 & 3,2 \\
& Wirausaha & 22 & 13,9 \\
& Satpam & 3 & 1,9 \\
\hline
\end{tabular}

\begin{tabular}{ccc}
\hline Berdasarkan & Jumlah & $\%$ \\
\hline Petani & 1 & 0,6 \\
Pedagang & 3 & 1,9 \\
IRT & 33 & 20,9 \\
\hline
\end{tabular}

Tabel 1 juga menunjukkan bahwa sebagian besar pendidikan orang tua adalah SMA $(57,6 \%)$ dan bekerja sebagai buruh $(46,8 \%)$. Dengan demikian, status sosial ekonomi sampel penelitian ini lebih cenderung menengah ke bawah.

Selanjutnya, survei dilakukan dengan membagikan kuesioner secara daring menggunakan Google Form. Google Form tersebut diserahkan kepada guru kelas kemudian guru kelas menyebarluaskan kepada para siswanya melalui Whatsapp Group.

Kuesioner dalam penelitian ini mengadaptasi penelitian Arofah (2009) mengenai persepsi siswa terhadap penerapan e-learning. Kisi-kisi kuesioner tersebut dapat dilihat pada Tabel 2, sedangkan detail pertanyaan dalam kuesioner ada pada Tabel 4.

Tabel 2. Kisi-kisi instrumen kuesioner persepsi

\begin{tabular}{llll}
\hline Indikator & \multicolumn{1}{c}{ Deskripsi } & Item \\
\hline Minat & $\begin{array}{l}\text { Perasaan siswa terhadap pembelajaran matematika berbasis } \\
\text { daring }\end{array}$ & $1+$ \\
& $\begin{array}{l}\text { Ketertarikan ssiwa dalam mengikuti pembelajaran matematika } \\
\text { berbasis daring }\end{array}$ & $2+, 4+$ \\
Penggunaan & $\begin{array}{l}\text { Pengalaman siswa mengikuti pembelajaran matematika } \\
\text { berbasis daring }\end{array}$ & $7-, 10-$ \\
& $\begin{array}{l}\text { Keterlambatan siswa dalam } \\
\text { matematika berbasis daring }\end{array}$ & mengikuti pembelajaran & $8+, 9+$ \\
& $\begin{array}{l}\text { Pandangan siswa dalam mengikuti pembelajaran matematika } \\
\text { berbasis daring }\end{array}$ & $3+, 6+$ \\
$\begin{array}{l}\text { Pemahaman siswa dalam mengikuti pembelajaran matematika } \\
\text { berbasis daring }\end{array}$ & $5+$
\end{tabular}

Tabel 2 menunjukkan dua faktor dalam persepsi siswa, yaitu minat belajar dan penggunaan pembelajaran matematika secara daring. Penskoran untuk tiap item adalah 0 dan 1 dengan jawaban ada dua kemungkinan, Ya dan Tidak. Item negatif (unfavorable) adalah 7 dan 10, selain itu adalah item positif (favorable). Untuk item positif, skor 1 untuk Ya dan 0 untuk Tidak. 
Kebalikannya, item negatif mendapat skor 0 untuk Ya dan 1 untuk tidak.

Setelah survei, dilakukan wawancara terhadap enam anak untuk mendapatkan jawaban yang lebih detail. Detail identitas responden wawancara dapat dilihat pada Tabel 3.

Tabel 3. Profil responden wawancara

\begin{tabular}{lccc}
$\begin{array}{c}\text { Tingkat } \\
\text { Kognitif }\end{array}$ & Nama & Kelas & $\begin{array}{c}\text { Jenis } \\
\text { Kelamin }\end{array}$ \\
\hline Tinggi & CA & IV A & Perempuan \\
& AB & IV B & Laki-laki \\
& SI & IV C & Laki-laki \\
Rendah & RA & IV A & Laki-laki \\
& LU & IV B & Perempuan \\
& TS & IV C & Perempuan \\
\hline
\end{tabular}

Keenam siswa pada Tabel 3 dipilih berdasarkan informasi guru dan didasarkan pada tingkat kognitifnya, yaitu 3 siswa tingkat kognitif tinggi dan 3 siswa tingkat kognitif rendah. Kecuali RA yang berumur 9 tahun, semua responden berumur 10 tahun.

Wawancara dilakukan melalui zoom dan video call melalui aplikasi WhatsApp. Protokol wawancara yang disusun tidak jauh berbeda dengan pertanyaan-pertanyaan dalam kuesioner.
Wawancara semi terstruktur digunakan untuk mengeksplorasi temuan-temuan yang unik dan mungkin tak terduga.

Data yang diperoleh dari kuesioner dianalisis menggunakan statistika deskriptif, mencakup persentase dan jumlah skor. Reliabilitas instrumen dianalisis menggunakan SPSS dan memperoleh koefisien sebesar 0,826, sehingga memadai.

Wawancara yang direkam dan ditranskripkan, kemudian dikodekan berdasarkan pola yang unik dan menarik. Dari interpretasi masingmasing peneliti, temuan didiskusikan dan revisi berdasarkan diskusi antar peneliti. Triangulasi sumber yang diperoleh dari masing-masing responden digunakan untuk menjamin kualitas temuan.

\section{HASIL DAN PEMBAHASAN \\ Data Deskriptif}

Hasil kuesioner terkait persepsi siswa dalam pembelajaran matematika secara daring disajikan secara deskriptif. Data deskriptif tersebut dapat dilihat pada Tabel 4.

Tabel 4. Hasil kuesioner siswa

\begin{tabular}{|c|c|c|c|c|}
\hline \multirow{2}{*}{ No } & \multirow{2}{*}{ Pertanyaan } & \multicolumn{2}{|c|}{ Hasil } & \multirow{2}{*}{$\begin{array}{l}\text { Jumlah } \\
\text { Skor }\end{array}$} \\
\hline & & $\mathbf{Y a}$ & Tidak & \\
\hline 1. & $\begin{array}{l}\text { Apakah Anda setuju jika pembelajaran } \\
\text { matematika secara daring diterapkan di sekolah? }\end{array}$ & $32,9 \%$ & $67,1 \%$ & 26 \\
\hline 2. & $\begin{array}{l}\text { Apakah Anda lebih senang jika pembelajaran } \\
\text { matematika menggunakan daring? }\end{array}$ & $19 \%$ & $81 \%$ & 15 \\
\hline 3. & $\begin{array}{l}\text { Apakah penerapan pembelajaran daring berguna } \\
\text { bagi Anda dalam mempelajari matematika? }\end{array}$ & $36,7 \%$ & $63,3 \%$ & 29 \\
\hline 4. & $\begin{array}{l}\text { Apakah pembelajaran matematika secara daring } \\
\text { menarik bagi Anda? }\end{array}$ & $34,2 \%$ & $65,8 \%$ & 27 \\
\hline 5. & $\begin{array}{l}\text { Dengan pembelajaran daring, apakah dapat } \\
\text { membantu Anda untuk lebih mudah mengerti } \\
\text { matematika? }\end{array}$ & $25,3 \%$ & $74,7 \%$ & 20 \\
\hline
\end{tabular}


DOI: https://doi.org/10.24127/ajpm.v10i3.3533

\begin{tabular}{llccc}
\hline \multirow{2}{*}{ No } & \multicolumn{1}{c}{ Pertanyaan } & \multicolumn{2}{c}{ Hasil } & Jumlah \\
\cline { 2 - 3 } & Ya & Tidak & Skor \\
\hline 6. $\begin{array}{l}\text { Apakah Anda termotivasi untuk mempelajari } \\
\text { matematika dengan menggunakan pembelajaran } \\
\text { daring? }\end{array}$ & $32,9 \%$ & $67,1 \%$ & 26 \\
7. Apakah dengan pembelajaran daring, Anda sudah \\
$\begin{array}{l}\text { tidak perlu bertatap muka dengan guru setiap } \\
\text { hari? }\end{array}$ & $19 \%$ & $81 \%$ & 64 \\
8. Apakah dengan pembelajaran daring, Anda dapat & $34,2 \%$ & $65,8 \%$ & 27 \\
$\begin{array}{l}\text { menerapkan pembelajaran matematika dalam } \\
\text { kehidupan sehari-hari? }\end{array}$ & & & \\
9. Apakah dengan pembelajaran matematika daring, & $30,4 \%$ & $69,6 \%$ & 24 \\
$\begin{array}{l}\text { waktu yang Anda gunakan lebih efisien? } \\
\text { 10. Apakah terdapat kesulitan dalam memahami } \\
\text { pelajaran matematika jika menggunakan daring? }\end{array}$ & $83,5 \%$ & $16,5 \%$ & 13 \\
\hline
\end{tabular}

Berdasarkan Tabel 4, menunjukkan bahwa persepsi siswa terhadap pembelajaran matematika secara daring cenderung mengarah kepada persepsi negatif. Salah satu buktinya dapat ditunjukkan dengan persentase respon siswa terhadap butir pertanyaan 2, 7 dan 10 yang rata-rata hampir $75 \%$ menyatakan tidak berminat dan tidak menghendaki penerapan pembelajaran matematika secara daring. Pada butir pertanyaan 2, terlihat bahwa $81 \%$ siswa tidak senang jika pembelajaran matematika menggunakan pembelajaran berbasis daring dan yang merasa senang hanya $19 \%$. Begitu pula butir pertanyaan $7,81 \%$ siswa menyatakan bahwa masih perlu pembelajaran tatap muka langsung dengan guru setiap hari. Hal tersebut didukung dengan hasil jawaban butir pertanyaan 10 yang menyatakan bahwa 83,5\% siswa merasa kesulitan dalam memahami pelajaran matematika jika menggunakan daring. Tabel 4 juga menyajikan skor keseluruhan untuk masing-masing item yang menguatkan temuan di atas.

Temuan penelitian ini sejalan dengan beberapa peneliti (Chiu et al.,
2021; Rasmitadila et al., 2020) yang menyebutkan bahwa dari waktu ke waktu siswa mengalami kemunduran minat dan motivasi terhadap belajar dan melibatkan diri dalam pembelajaran secara daring. Hal ini dikarenakan pembelajaran daring bagi siswa tidak menarik, tidak efisien, dan sulit untuk memahami materi matematika. Adanya kesulitan dalam pembelajaran daring juga menyebabkan siswa tidak dapat menerapkan pembelajaran matematika di kehidupan sehari-hari. Selain itu, pekerjaan rumah yang diberikan kepada siswa lebih banyak dibanding pembelajaran tatap muka, sehingga anak seringkali stress, cemas dan kelelahan. Ditambah, kondisi infrastruktur teknologi dan lingkungan yang tidak mendukung untuk proses pembelajaran daring.

Di samping kebijakan pemerintah yang mendukung pembelajaran daring, keterlibatan orang tua siswa, modifikasi pengajaran guru dan media yang relevan, pengaturan diri dari siswa itu sendiri sangat dibutuhkan menghadapi perubahan untuk pembelajaran matematika secara daring (Chiu et al., 2021; Fung et al., 2021). 


\section{Studi Kasus Enam Siswa Dengan Variasi Tingkat Kognisi}

Pada bagian ini, disajikan temuan dari enam siswa yang dipilih berdasarkan tingkat kognisi melalui wawancara semi terstruktur. Tiga siswa di masing-masing level dideskripsikan pada Tabel 3.

\section{Minat tidak selalu berbanding lurus dengan Kognisi}

Hasil wawancara penelitian ini menunjukkan bahwa 5 dari 6 siswa menyatakan suka terhadap pembelajaran matematika. Responden CA dengan kognitif tinggi mengatakan bahwa dia sangat menyukai mata pelajaran matematika karena mudah dipahami dan nilai dari mata pelajaran matematika selalu bagus. Berikut potongan wawancara dengan $\mathrm{CA}$ :

"Saya suka banget pelajaran matematika, karena mudah dipahami dan nilainya selalu bagus". (Wawancara, 21 November 2020)

Sedangkan untuk Responden dengan tingkat kognitif rendah mereka juga sama-sama suka dan memiliki ketertarikan atau minat dalam belajar mata pelajaran matematika. Dengan melihat hasil wawancara dengan ketiga Responden RA, LU, dan TS. Dua dari tiga Responden tersebut memiliki ketertarikan dan minat belajar mata pelajaran matematika. Responden LU mengemukakan bahwa dia suka belajar matematika apabila dia bisa menjawab soal-soal atau pertanyaan dengan benar. Responden LU mengatakan bahwa:

"Saya suka belajar matematika, karena setiap mendapat jawaban yang tepat, saya senang." (Wawancara, 21 November 2020)
Berdasarkan uraian hasil potongan wawancara di atas, ditemukan tingkat ketertarikan siswa terhadap mata pelajaran matematika tidak dipengaruhi oleh tingkat kognitif siswa. Lima dari enam siswa yang diwawancara menunjukkan bahwa mereka suka terhadap pelajaran matematika.

Di satu sisi, temuan ini mungkin berbeda dengan pendapat Ulya (2015) yang menyatakan bahwa rendahnya kemampuan matematika menyebabkan munculnya sikap ketidaksenangan siswa terhadap pelajaran matematika dan begitu sebaliknya. Namun demikian, di sisi lain, juga sejalan karena menunjukkan bahwa siswa dengan kognisinya bagus cenderung memiliki minat yang baik. Temuan ini juga mengindikasikan bahwa sebagian besar siswa sekolah dasar dengan level kognisi rendah juga senang matematika karena terkait persepsi mereka terhadap matematika sebagai kumpulan angka dan meliputi kegiatan berhitung dan bernyanyi (Metzger et al., 2019; Wernet \& Nurnberger-Haag, 2015) dan tidak berlama-lama fokus pada kekurangan mereka serta pada umumnya resiliensi anak kecil masih bagus untuk seusia mereka. Meskipun demikian, kelemahan ini perlu menjadi perhatian serius bagi guru khususnya dalam memberikan umpan balik harus konstruktif sehingga siswa terbangun resiliensi matematik, self-efficacy beliefs dan konsepsi matematika yang konstruktif pula (Purnomo, 2015, 2016, 2017a).

\section{Kognisi dan Motivasi: tidak selalu sejalan}

Penelitian ini mengidentifikasi bahwa siswa dengan tingkat kognitif tinggi tidak menunjukkan adanya motivasi untuk belajar matematika dengan menggunakan daring. 
Berbanding terbalik dengan siswa dengan tingkat kognitif rendah, mereka menunjukkan adanya motivasi untuk mengikuti pembelajaran matematika secara daring. Sebagai contoh, responden $\mathrm{CA}$ dengan kognitif tinggi mengemukakan bahwa dia tidak termotivasi untuk mengikuti pembelajaran matematika secara daring karena tidak dijelaskan langsung oleh gurunya. Responden CA mengatakan bahwa:

"Saya tidak termotivasi mengikuti pembelajaran matematika secara daring karena tidak dijelaskan langsung oleh guru." (Wawancara, 21 November 2020)

Sedangkan untuk responden dengan tingkat kognitif rendah, dua dari tiga responden lebih termotivasi dengan adanya pembelajaran daring yang dilakukan oleh guru dan sekolah. Sebagai contoh, responden RA dengan tingkat kognitif rendah mengemukakan bahwa RA termotivasi dengan pembelajaran matematika secara daring. Motivasi ini terkait dengan kedekatan dan dorongan semangat dari orang tuanya, yang lebih daripada pembelajaran biasa, walaupun ada rasa jenuh karena belajar daring terus menerus. Berikut potongan wawancara dengan Responden RA:

"Saya termotivasi karena disemangati oleh ibu saya. Tetapi sebenarnya saya jenuh dengan belajar online ini." (Wawancara, 21 November 2020)

Berdasarkan potongan hasil wawancara di atas, penelitian ini menemukan bahwa tingkat motivasi siswa terhadap pembelajaran matematika secara daring tidak dipengaruhi oleh tingkat kognitif siswa.
Tiga siswa yang memiliki tingkat kognitif tinggi justru kurang memiliki motivasi untuk mengikuti pembelajaran matematika secara daring. Sedangkan dua dari tiga siswa yang memiliki tingkat kognitif rendah justru memiliki motivasi yang tinggi untuk mengikuti pembelajaran matematika secara daring. Temuan ini kontradiksi dengan temuan penelitian-penelitian yang relevan sebelumnya (Ferrer et al., 2020; Karaali, 2015). Namun demikian, kami beragumen bahwa ini terjadi karena penelitian kami fokus pada pembelajaran matematika secara daring, yang mana sampel kami, siswa sekolah dasar adalah fase yang mengedepankan pada aktivitas dan bersosial. Kebosanan juga menjadi penyebab mereka tidak nyaman dengan pembelajaran matematika secara daring, aktivitas eksplorasi, reinvention, dan berdiskusi menjadi terbatas. Ini berbanding terbalik dengan siswa dengan kognisi rendah, dimana mereka berada pada zona nyaman ketika pembelajaran daring dan dirasa lebih santai daripada pembelajaran tatap muka.

\section{KESIMPULAN DAN SARAN}

Temuan penelitian ini mengindikasikan bahwa persepsi siswa terhadap pembelajaran matematia secara daring adalah negatif. Hal tersebut dapat diartikan bahwa pembelajaran secara daring dipersepsikan siswa kurang efektif dan cenderung membosankan jika diterapkan dalam mata pelajaran matematika khususnya di sekolah dasar. Ini menjadi pekerjaan bersama baik pembuat kebijakan, sekolah, guru, orang tua untuk bersama-sama terlibat secara penuh untuk memaksimalkan potensi anak meskipun pembelajaran matematika dilakukan secara daring. Di samping infrastruktur teknologi, 
dukungan dan pengawasan orang tua, media dan sumber belajar yang relevan dengan pembelajaran ini perlu menjadi perhatian.

Beberapa saran dan rekomendasi untuk penelitian selanjutnya berdasarkan temuan penelitian ini, adalah penggunaan sampel yang lebih banyak dan mewadai karakteristik demografis, misalnya sosial ekonomi orang tua. Kami juga mengidentifikasi pentingnya bagaimana mengkaji peran orang tua, dan sumber belajar dalam pembelajaran matematika secara daring ini.

\section{DAFTAR PUSTAKA}

Arofah, L. (2009). Penerapan Pembelajaran Berbasis ELearning pada pokok bahasan Operasi Aljabar Kelas VIII di Sekolah Nasional Plus InggrisMandarin Pelita Bangsa Denpasar [UIN Sunan Ampel Surabaya]. http://digilib.uinsby.ac.id/id/eprint/ 7899

Chiu, T. K. F., Lin, T.-J., \& Lonka, K. (2021). Motivating Online Learning: The Challenges of COVID-19 and Beyond. The AsiaPacific Education Researcher, 30(3), 187-190. https://doi.org/10.1007/s40299021-00566-w

Ferrer, J., Ringer, A., Saville, K., A Parris, M., \& Kashi, K. (2020). Students' motivation and engagement in higher education: the importance of attitude to online learning. Higher Education. https://doi.org/10.1007/s10734020-00657-5

Fung, J. J. Y., Yuen, M., \& Yuen, A. H. K. (2021). Online Learning for Mathematically Talented Students: A Perspective from Hong Kong. In Smith S.R. (Ed.), Handbook of
Giftedness and Talent Development in the Asia-Pacific (pp. 857-884). Springer. https://doi.org/10.1007/978-98113-3041-4_39

Karaali, G. (2015). Metacognition in the Classroom: Motivation and SelfAwareness of Mathematics Learners. Primus, 25(5), 439-452. https://doi.org/10.1080/10511970.2 015.1027837

Markovits, Z., \& Forgasz, H. (2017). "Mathematics is like a lion": Elementary students' beliefs about mathematics. Educational Studies in Mathematics, 96(1), 49-64. https://doi.org/10.1007/s10649017-9759-2

Metzger, S. R., Sonnenschein, S., \& Galindo, C. (2019). Elementaryage children's conceptions about mathematics utility and their home-based mathematics engagement. Journal of Educational Research, 112(4), 431-446.

https://doi.org/10.1080/00220671.2 018.1547961

Moore, J. L., Dickson-Deane, C., \& Galyen, K. (2011). E-Learning, online learning, and distance learning environments: Are they the same? Internet and Higher Education, 14(2), 129-135. https://doi.org/10.1016/j.iheduc.20 10.10 .001

Ningsih, S. (2020). Persepsi Mahasiswa Terhadap Pembelajaran Daring Pada Masa Pandemi Covid-19. JINOTEP (Jurnal Inovasi Dan Teknologi Pembelajaran): Kajian Dan Riset Dalam Teknologi Pembelajaran, 7(2), 124-132. https://doi.org/10.17977/um031v7i 22020p124

Purnomo, Y. W. (2015). Pengembangan desain pembelajaran berbasis 
DOI: https://doi.org/10.24127/ajpm.v10i3.3533

penilaian dalam pembelajaran matematika. Cakrawala Pendidikan, XXXIV(2), 182-191. https://doi.org/10.21831/cp.v2i2.48 23

Purnomo, Y. W. (2016). Perbaikan Instruksional dalam Implementasi Assessment-Based Learning di Kelas Matematika. Cakrawala Pendidikan, XXXV(3), 403-411. https://doi.org/10.21831/cp.v35i3.8 821

Purnomo, Y. W. (2017a). The complex relationship between teachers' mathematics-related beliefs and their practices in mathematics class. The New Educational Review, 47(1), 200-210. https://doi.org/10.15804/tner.2017. 47.1.16

Purnomo, Y. W. (2017b). A Scale for Measuring Teachers' MathematicsRelated Beliefs: A Validity and Reliability Study. International Journal of Instruction, 10(2), 2338. https://doi.org/10.12973/ iji.2017.1022a

Purnomo, Y. W., Suryadi, D., \& Darwis, S. (2016). Examining preservice elementary school teacher beliefs and instructional practices in mathematics class. International Electronic Journal of Elementary Education, 8(4), 629-642. https://www.iejee.com/index.php/I EJEE/article/view/137

Rasmitadila, R., Aliyyah, R. R., Rachmadtullah, R., Samsudin, A., Syaodih, E., Nurtanto, M., \& Tambunan, A. R. S. (2020). The Perceptions of Primary School Teachers of Online Learning during the COVID-19 Pandemic Period: A Case Study in Indonesia. Journal of Ethnic and Cultural Studies, $\quad 7(2), \quad 90$. https://doi.org/10.29333/ejecs/388
Ulya, H. (2015). Hubungan Gaya Konitif Kemampuan Pemecahan Masalah Matematika Siswa. Jurnal Konseling GUSJIGANG, 1(2). https://doi.org/10.24176/jkg.v1i2.4 10

Wernet, J. L., \& Nurnberger-Haag, J. (2015). Toward broader perspectives of young children's mathematics: Recognizing and comparing Olivia's beliefs and activity. Contemporary Issues in Early Childhood, 16(2), 118-141. https://doi.org/10.1177/146394911 5585442

Zamista, A. A., Rahmi, H., Sellyana, A., \& Desriyati, W. (2020). Persepsi Mahasiswa terhadap Pembelajaran dalam Jaringan untuk Mata Kuliah Kalkulus. Jurnal THEOREMS (The Original Research of Mathematics), 5(1), 41. https://doi.org/10.31949/th.v5i1.22 14 